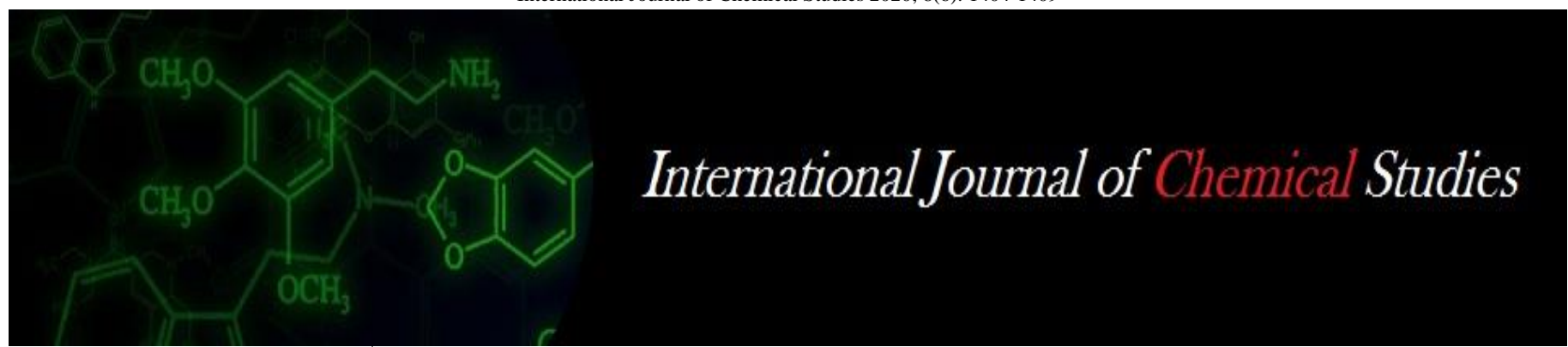

P-ISSN: 2349-8528

E-ISSN: 2321-4902

www.chemijournal.com

IJCS 2020; 8(6): 1404-1409

(C) 2020 IJCS

Received: 05-08-2020

Accepted: 15-10-2020

\section{Mevada KD}

Associate Professor, Department of Agronomy, B.A. College of Agriculture, Anand Agricultural University, Anand, Gujarat, India

Choudhary Ram Niwas

Assistant Research Scientist, Agricultural Research Station, AAU, Dhandhuka, Gujarat, India

\section{Saiyad MM}

Agricultural Officer, College of

Agriculture, AAU, Vaso,

Gujarat, India

\section{Corresponding Author:}

Mevada KD

Associate Professor, Department of Agronomy, B.A. College of Agriculture, Anand Agricultural University, Anand, Gujarat, India

\section{Influence of seed soaking and foliar spray of stress mitigating bio-regulators on growth and yield attributes, yield and economics of durum wheat under conserved soil moisture condition}

\author{
Mevada KD, Choudhary Ram Niwas and Saiyad MM
}

DOI: https://doi.org/10.22271/chemi.2020.v8.i6t.10959

\title{
Abstract
}

A field experiment was conducted at Agricultural Research Station, Anand Agricultural University, Dhandhuka (Gujarat) during two consecutive rabi seasons of 2017-18 and 2018-19 to determine the effect of seed soaking and foliar spray of stress mitigating bio-regulators on productivity of durum wheat under conserved soil moisture condition. The experiment was laid out in randomized block design (factorial) with four replications under conserve moisture condition with sixteen treatment combinations comprising of four seed soaking treatments viz; $\mathrm{S}_{0}$ :no seed soaking, $\mathrm{S}_{1}$ :seed soaking with water, $\mathrm{S}_{2}$ :seed soaking with salicylic acid @ 100 ppm and S3:seed soaking with thiourea@ 500 ppm; and four foliar spray treatments viz; $\mathrm{C}_{0}$ : no spray, $\mathrm{C}_{1}$ : foliar spray water spray, $\mathrm{C}_{2}$ :foliar spray with salicylic acid @ 100 ppm and $\mathrm{C}_{3}$ : foliar spray with thiourea @ 1000 ppm, twice at tillering stage (40-45 DAS) and at ear emergence (65 -70 DAS) stage. Results of the two years experiment showed that seed soaking with salicylic acid @ 100 ppm recorded significantly higher growth parameters viz; plant height (at 60 and 90 DAS and at harvest) and dry matter accumulation (at 60 and 90 DAS and at harvest). Likewise, yield attributes viz, tiller conversion index, length of spike per plant, number of spikelet per spike, number of grains per spike and test weight were recorded significantly higher under seed soaking with 100 ppm salicylic acid. The same treatment produced significantly higher grain and straw yield. However, it remained at par with seed soaking with $500 \mathrm{ppm}$ thiourea treatment. Foliar spray twice at tillering stage (40-45 DAS) and at ear emergence (65 -70 DAS) stage with salicylic acid @ 100 ppm observed significantly higher growth parameters viz; plant height (at 60 and 90 DAS and at harvest) as well as dry matter accumulation (at 60 and 90 DAS and at harvest). In the same way, foliar spray with 100 ppm salicylic acid, being at par with foliar spray with $1000 \mathrm{ppm}$ thiourea, reported significantly higher yield attributes viz, tiller conversion index, length of spike per plant, number of spikelet per spike, number of grains per spike and test weight over no spray and water spray. The same treatment produced significantly higher grain and straw yield. As far as economics was concerned, higher net return and BCR were realized under seed soaking with $100 \mathrm{ppm}$ salicylic acid and foliar spray with 100 ppm salicylic acid, followed by seed soaking and foliar application with thiourea @ 500 ppm and 1000 ppm, respectively.

Keywords: Durum wheat, foliar spray, salicylic acid, seed soaking, thiourea

\section{Introduction}

Durum wheat (Triticum durum L.) is the second most important species globally as well as nationally grown after bread wheat (Triticum aestivum L.). Total durum wheat production in India is sharing about 4 to 10 per cent of total wheat production (Anon., 2017) ${ }^{[4]}$. In Gujarat, cultivation of durum wheat under conserved moisture is mainly concentrated in Bhal area comprising the parts of Ahmedabad, Bhavnagar, Kheda and Surendranagar districts and it is also grown in Vagra, Jambusar and Amod talukas of Bharuch district and in Ghed area of Porbandar district. The area under unirrigated wheat cultivation during the year 2017-18 was 0.52 lakh hectares with an annual production of 0.54 lakh tonnes (Anon., 2018) ${ }^{[5]}$. The productivity of Duram wheat is determined by genotypes, soil moisture availability and environmental conditions. Durum wheat is cultivated on conserve soil moisture received in the month of September in Bhal and Coastal region of Gujarat during rabi season. The lower productivity of durum wheat could mainly pertain to moisture stress during germination and 
Heat stress during later phenological stages. The problem of germination is frequently occurred due to seed dormancy because of insufficient soil moisture condition during germination (Hall, 2011) ${ }^{[13]}$. Due to climate change heat stress at maturity stage also becomes a regular phenomenon in recent years and drought is the most limiting factor in production in semi-arid ecosystem of Gujarat. Soaking of seeds and /or spraying the crop with water and / or some bioregulators is one of the proven technologies to mitigate the illeffect of moisture and heat stress on productivity of Duram wheat by enhancing proper germination and developing heat stress tolerance in the crop. Bio-regulator is a group of naturally occurring growth promoting phytohormones, which regulates several physiological processes like cell division, cell elongation, and synthesis of nucleic acid and proteins (Mandava, 1988). Use of bio-regulators has offered new avenues for enhancing productivity of several crops. It has been reported that bio-regulators play important role in greater partitioning of photosynthates towards reproductive sink there be improving the harvest index (Kumar et al. 2018) [20]. Thiourea, a sulphydryl compound, also called thiocarbamide, an organic compound that resembles urea but contains sulphur instead of oxygen; i.e., the molecular formula is $\mathrm{CS}\left(\mathrm{NH}_{2}\right)^{2}$, while that of urea is $\mathrm{CO}\left(\mathrm{NH}_{2}\right)^{2}$, contains one $-\mathrm{SH}$ group besides containing nitrogen in the form of $-\mathrm{NH}_{2}$, plays several bio-regulatory roles in crop plants, as the $-\mathrm{SH}$ group has diverse biological activities. Thiourea has been reported to have a role in improving photosynthetic efficiency and translocation of photosynthates (Sahu et al., 1993) ${ }^{[27]}$. Salicylic acid, $\mathrm{C}_{7} \mathrm{H}_{6} \mathrm{O}_{3}$, is a naturally existing phenolic compound and is considered to be a potent plant growth regulator because of its diverse regulatory role in plant metabolism. It is a lipophilic monohydroxybenzoic acid, a type of phenolic acid, and a beta hydroxy acid (BHA). Phenolics play important roles in plant development, particularly in lignin and pigment biosynthesis. They also provide structural integrity and scaffolding support to plants. Though there are various studies about the use of bioregulators as moisture and heat stress mitigates through seed soaking and foliar spray augment productivity of wheat cultivated under conserve soil moisture conditions are done in India and abroad, but there is a dearth of research on this aspect in Gujarat; therefore, a study is planned to ascertain the effect of seed soaking and foliar spray of stress mitigating bio-regulators on growth, yields attributes and yield of durum wheat.

\section{Materials and Methods}

A field experiment was conducted at Agricultural Research Station, Anand Agricultural University, Dhandhuka (Gujarat) during two consecutive rabi seasons of 2017-18 and 2018-19 to determine the effect of seed soaking and foliar spray of stress mitigating bio-regulators on productivity of durum wheat under conserved soil moisture condition. Total sixteen treatment combinations comprising of four seed soaking treatments viz; $\mathrm{S}_{0}$ :no seed soaking, $\mathrm{S}_{1}$ :seed soaking with water, $\mathrm{S}_{2}$ :seed soaking with salicylic acid@100 ppm and $\mathrm{S}_{3}$ :seed soaking with thiourea @ 500 ppm; and four foliar spray treatments viz; $\mathrm{C}_{0}$ : no spray, $\mathrm{C}_{1}$ : foliar spray water spray, $\mathrm{C}_{2}$ :foliar spray with salicylic acid @ 100 ppm and $\mathrm{C}_{3}$ : foliar spray with thiourea @ 1000 ppm, twice at tillering stage (40-45 DAS) and at ear emergence (65 -70 DAS) stage, were tried out in randomized block design (factorial) with four replications. Seeds of Durum wheat variety GADW-3 were soaked with water, $100 \mathrm{ppm}$ salicylic acid $(0.1 \mathrm{ml} / 1$ lit. water for $\mathrm{kg}$ of seed) and $500 \mathrm{ppm}$ thiourea $(0.5 \mathrm{~g} / \mathrm{lit}$ of water per $\mathrm{kg}$ seed) solution for two hours, air dried in shadow and then used for drilling at $30 \mathrm{~cm}$ spacing and full recommended dose of nitrogen $(20 \mathrm{~kg} \mathrm{~N} / \mathrm{ha})$ and phosphorus (12.5 kg $\left.\mathrm{P}_{2} \mathrm{O}_{5} / \mathrm{ha}\right)$ were applied in the form of urea and single super phosphate, respectively as basal at the time of sowing in all the plots. Water, $100 \mathrm{ppm}$ salicylic acid (1 ml/ 10 lit. water; total 500 lit water/ha) and $1000 \mathrm{ppm}$ thiourea (10 g/10 lit of water; total 500 lit water/ha) were foliar sprayed twice at tillering stage (40-45 DAS) and at ear emergence (65 -70 DAS) stage.

Tiller conversion Index (\%) was calculated by counting the number of tillers having fully developed ear from the randomly selected square meter in each plot by following formula.

\section{Tiller conversion Index $=\frac{\text { No. of effective tillers }}{\text { Total no. of tillers }} \times 100$}

Economics were calculated on the basis of current prices of the inputs and produce. Benefit cost ratio (BCR) and Incremental cost benefit ratio (ICBR) were calculated using following formulae.

Benefit cost ratio $(\mathrm{BCR})=\frac{\text { Gross return }(/ \mathrm{ha})}{\text { Total cost of cultivation ( } / \mathrm{ha})}$

Net Incremental cost benefit ratio $(\mathrm{ICBR})=\frac{\text { Net Incremental cost }(\mathrm{C} / \mathrm{ha})}{\text { Net Incremental income }(\mathrm{ha})}$

\section{Results and Discussion}

1. Growth ParameterS

\section{a. Effect of seed soaking}

A critical examination of data (Table 1) indicated that though plant height as well as dry matter accumulation at initial stage i.e. at 30 DAS was not affected remarkably due to seed soaking treatments, later growth stages i.e. 60 and 90 DAS and at harvest an increase in plant height and dry matter accumulation was more pronounced on pooled analysis. Seed soaking with salicylic acid $(100 \mathrm{ppm})\left(\mathrm{S}_{2}\right)$, being at par with thiourea $(500 \mathrm{ppm})\left(\mathrm{S}_{3}\right)$, recorded significantly higher plant height $(40.99 \mathrm{~cm}, 76.10 \mathrm{~cm}$ and $87.32 \mathrm{~cm})$ and dry matter accumulation $(111.59 \mathrm{~g}, 195.60 \mathrm{~g}$ and $268.58 \mathrm{~g})$ at 60 and 90 DAS and at harvest, respectively. Application of seed soaking with salicylic acid (100 ppm) represented an increase to the tune of 14.15 and 12.39 per cent at 60 DAS, 10.40 and 8.89 per cent at 90 DAS and 11.62 and 8.89 per cent at harvest for plant height and 20.18 and 17.60 per cent at $60 \mathrm{DAS}, 28.69$ and 23.03 per cent at 90 DAS and 30.71 and 24.46 per cent at harvest for dry matter accumulation over no seed soaking $\left(\mathrm{S}_{0}\right)$ and seed soaking with water $\left(\mathrm{S}_{1}\right)$ on pooled basis, respectively. The treatment of seed soaking with thiourea $(500 \mathrm{ppm})\left(\mathrm{S}_{3}\right)$ was found significantly superior over no seed soaking $\left(\mathrm{S}_{0}\right)$ and seed soaking with water $\left(\mathrm{S}_{1}\right)$ at 60 and 90 DAS and at harvest on pooled basis.

Seed soaking significantly improved the emergence and growth of plant. Seed soaking with salicylic acid increased tiller density, dry matter accumulation, leaf area index (Jatana et al., 2020) ${ }^{[16]}$. The positive action of salicylic acid on growth could be ascribed due to one or a number of reasons. Salicylic acid (mono-hydroxybenzoic acid, SA) is a naturally occurring, water soluble, hormone-like, non-enzymatic phenolic antioxidant, involved in various stress tolerance mechanisms (Janda et al., 2014) ${ }^{[15]}$. It is a vital signalling molecule that modulates plant responses against abiotic stresses (Nazar et al., 2011; Li et al., 2014) ${ }^{[25,21]}$. Salicylic 
acid mediated regulation of various physiological and biochemical processes indicated its role in plant stress tolerance (Abreu and Bosch, 2009; Ashraf et al., 2018) ${ }^{[1,6]}$. The involvement of $-\mathrm{SH}$ group in phloem for sucrose transport was also noted by Giaquinta (1976) [12]. Furthermore, it also stimulates synthesis of photosynthetic pigments, quaternary ammonium compounds and up regulates the antioxidative system (Khan et al., 2012; Miura and Tada, $2014)^{[18,24]}$. The favourable effect of salicylic acid on growth of plants might be due to it involves in nutrient uptake and translocation, water and stomatal regulations and antioxidant defence (Arfan et al., 2007) ${ }^{[6]}$.

\section{b. Effect of foliar spray}

Data presented in Table 1 indicated that foliar spray of stress mitigating bio-regulators significantly increased the plant height and dry matter accumulation. Foliar spray with 100 ppm salicylic acid $\left(\mathrm{C}_{2}\right)$ and Foliar spray with $1000 \mathrm{ppm}$ thiourea spray $\left(\mathrm{C}_{3}\right)$ being at par with each other recorded significantly higher plant height and dry matter accumulation at 60 and 90 DAS and at harvest in pooled analysis over no spray $\left(\mathrm{C}_{0}\right)$ and water spray $\left(\mathrm{C}_{1}\right)$, however, at early growth stage at 30 DAS bio-regulators failed to exert nay remarkable impact on plant height as well as on dry matter accumulation. Foliar spray with $100 \mathrm{ppm}$ salicylic acid spray $\left(\mathrm{C}_{2}\right)$ enhanced the plant height up to 12.82 and 10.74 per cent at 60 DAS, 10.03 and 8.61 per cent at 90 DAS and 10.57 and 7.60 per cent at harvest and dry matter accumulation to the tune of 19.72 and 17.36 per cent at $60 \mathrm{DAS}, 21.51$ and 18.78 per cent at 90 DAS, 24.82 and 20.26 per cent at harvest over no spray $\left(\mathrm{C}_{0}\right)$ and water spray $\left(\mathrm{C}_{1}\right)$ on pooled basis, respectively, on pooled mean basis.

Beneficial effects of foliar spray with salicylic acid @ 100 ppm seems to be due to salicylic acid is an endogenous plant growth regulator of phenolic nature has been found to generate a wide range of metabolic and physiological responses in plants. The overall improvement in growth of crop with the addition of higher level of salicylic acid could be ascribed to its pivotal role in diverse physiological processes in plants which include thermogenesis, flower induction, nutrient uptake, ethylene biosynthesis, stomatal movement, photosynthesis and anti- oxidative enzymes (Hayat et al. 2010) ${ }^{[14]}$. Salicylic acid treatment was found to enhance the efficiency of antioxidant system in plants (Knorzer et al. 1999) [19]. The exogenous application of Salicylic acid enhanced the activities of antioxidant enzymes (CAT, POX and SOD) when sprayed exogenously to the drought stressed plants. Similar findings were reported by various researchers on bio-regulators spray and observed on significant crop growth with thiourea and salicylic acid might be attributed due to considerable increase in effective utilization of nutrient, moisture and light (Dadhich et al., 2015, Dadhich and Meena, 2014; Meena et al., 2014) ${ }^{[10,11,23] .}$

\section{B. Yield attributes and yield \\ a. Effect of seed soaking}

All the yield attributing parameters (Table 2) viz; tiller conversion index, length of spike, number of spikelet per spike, number of grains per spike and test weight were responded positively to seed soaking with salicylic acid (100 $\mathrm{ppm})$. The pooled data showed that the application of seed soaking with salicylic acid $(100 \mathrm{ppm})\left(\mathrm{S}_{2}\right)$ resulted into significantly higher tiller conversion index (81.49) on pooled basis which manifested 11.72 and 9.65 per cent increase in tiller conversion index over no seed soaking $\left(\mathrm{S}_{0}\right)$ and seed soaking with water $\left(\mathrm{S}_{1}\right)$, respectively. Similarly, significantly higher length of spike $(10.05 \mathrm{~cm})$, number of spikelet per spike (19.91), number of spikelet per spike (58.46) and test weight $(58.95 \mathrm{~g})$ was recorded for seed soaking with salicylic acid $(100 \mathrm{ppm})$, which remained identical with seed soaking with $500 \mathrm{ppm}$ thiourea $\left(\mathrm{S}_{3}\right)$ in pooled mean. Application of seed soaking with salicylic acid @ 100 ppm registered an enlargement of 25.47 and 23.01 per cent in length of spike, 33.53 and 29.79 per cent in number of spikelet per spike, 10.20 and 7.19 per cent over in number of grains per spike and 8.09 and 5.14 per cent in test weight over no seed soaking $\left(\mathrm{S}_{0}\right)$ and seed soaking with water $\left(\mathrm{S}_{1}\right)$, respectively, in pooled mean. An application of seed soaking with thiourea (500 ppm) $\left(\mathrm{S}_{3}\right)$, being at par with seed soaking with salicylic acid $(100 \mathrm{ppm})\left(\mathrm{S}_{2}\right)$, was found significantly superior over no seed soaking $\left(\mathrm{S}_{0}\right)$ and seed soaking with water $\left(\mathrm{S}_{1}\right)$ for all the yield attributes.

Similar trend was observed for grain and straw yield of wheat (Table 2), wherein, seed soaking with salicylic acid @ 100 ppm $\left(\mathrm{S}_{2}\right)$, produced significantly higher grain yield (2008 $\mathrm{kg} / \mathrm{ha})$ and straw yield $(2895 \mathrm{~kg} / \mathrm{ha})$ over no seed soaking $\left(\mathrm{S}_{0}\right)$ and seed soaking with water $\left(S_{1}\right)$ in pooled analysis, which recorded an increment to the tune of 27.74 and 23.27 per cent for grain and 31.83 and 30.00 percent for straw yield over no seed soaking and seed soaking with water, respectively. Seed soaking with $500 \mathrm{ppm}$ thiourea $\left(\mathrm{S}_{3}\right)$ being at par with salicylic acid @ $100 \mathrm{ppm}\left(\mathrm{S}_{2}\right)$, also produced significantly higher grain (1936 kg/ha) and straw (2786 kg/ha) yield over no seed soaking $\left(\mathrm{S}_{0}\right)$ and seed soaking with water on the pooled mean basis. An increment of 23.16 and 18.85 per cent for grain yield and 26.86 and 25.10 per cent for straw yield was recorded with seed soaking with $500 \mathrm{ppm}$ thiourea over no soaking and water soaking, respectively.

On understanding the diverse effect of salicylic acid on crop growth and development, it may be inferred that increase in yield attributes and yield obtained with salicylic acid @ 100 ppm seed soaking was most probably due to increased crop photosynthesis favoured by both improved photosynthetic efficiency and source to sink relationship. This may be attributed due to improvement in growth parameters and moreover, the proportionate distribution of dry matter at later stage of crop growth (Ahmad et al., 2018). Giauaint (1976) reported that the bio-regulatory effect of salicylic acid was chiefly through mobilization of dry matter and translocation of photosynthates to sink which ultimately significantly improved the grain yield. Thus, it is highly probable that in the present investigation, salicylic acid with its sulphydryl group not only favoured the green photosynthetic surface but might have also improved the activity of starch synthetase and hence, the effective filling of seeds.

\section{b. Effect of foliar spray}

A critical examination of data (Table 2) further exhibited that application of salicylic acid spray $(100 \mathrm{ppm}) \quad\left(\mathrm{C}_{2}\right)$ significantly increased tiller conversion index (81.51), length of spike $((10.05 \mathrm{~cm})$, number of spikelet per spike (19.70), number of grains per spike (58.54) and test weight (59.03 g) on pooled (81.51), however, it remained at par with thiourea spray $(1000 \mathrm{ppm})\left(\mathrm{C}_{3}\right)$ for all the attributes. On the basis of pooled basis, salicylic acid spray $\left(\mathrm{C}_{2}\right)$ registered an increase of 11.54 and 9.25 per cent for tiller conversion index, 24.07 and 21.67 per cent for length of spike, 30.82 and 26.39 per cent for number of spikelet per spike, 10.06 and 7.93 per cent for number of grains per spike and 8.03 and 6.34 per cent for test weight over no spray $\left(\mathrm{C}_{0}\right)$ and water spray $\left(\mathrm{C}_{1}\right)$, 
respectively. Foliar spray with $1000 \mathrm{ppm}$ thiourea $\left(\mathrm{C}_{3}\right)$ remaining statistically identical with $100 \mathrm{ppm}$ salicylic acid $\left(\mathrm{C}_{2}\right)$ spray, recorded significantly higher yield attributes over no spray $\left(\mathrm{C}_{0}\right)$ and water spray $\left(\mathrm{C}_{1}\right)$.

A close perusal of the data pointed out that foliar spray with 100 ppm salicylic acid spray $\left(\mathrm{C}_{2}\right)$, being at par with foliar spray with $1000 \mathrm{ppm}$ thiourea $\left(\mathrm{C}_{3}\right)$, generated considerably higher grain (1984 kg/ha) and straw (2859 kg/ha) yield over no spray $\left(C_{0}\right)$ and water spray $\left(C_{1}\right)$, on pooled basis. The pooled gain for grain yield obtained under salicylic acid spray were recorded to the tune of 23.69 and 20.90 per cent for grain yield and 28.26 and 26.17 per cent for straw yield over no spray $\left(\mathrm{C}_{0}\right)$ and water spray $\left(\mathrm{C}_{1}\right)$, respectively. While for thiourea spray the increase was recorded to the tune of 28.26 and 26.17 per cent for grain yield and 19.51 and 16.82 per cent for straw yield over no spray $\left(\mathrm{C}_{0}\right)$ and water spray $\left(\mathrm{C}_{1}\right)$, respectively.

An increase in yield attributes and yield obtained with salicylic acid was most probably due to augmented crop photosynthesis favoured by both enhanced photosynthetic efficiency and source to sink relationship. Further, it is relevant to point out that the response of foliar application of $100 \mathrm{ppm}$ salicylic acid at vegetative and flowering was more pronounced as compared to seed soaking. This may be attributed due to improvement in growth parameters and moreover, the proportionate distribution of dry matter at later stage of crop growth. Amin et al., $2008^{[3]}$ showed that foliar application of salicylic acid $(100 \mathrm{mg} / \mathrm{lit})$ resulted in the highest increase in yield and its components. Similar results were recorded by Ashraf et al., (2010) ${ }^{[8]}$ and Chouhan et al. (2017) ${ }^{[9]}$. Effect of salicylic acid was chiefly through mobilization of dry matter and translocation of photosynthates to sink which ultimately significant improved the seed yield. This is further evidenced from the fact that yield attributes viz. tiller conversion index, spike length, number of spikelet per spike, number of grains/spike and test weight increased significantly under crop sprayed with salicylic acid, which ultimately resulted in higher seed yield (Karim et al. 2011)
[17]. The straw yield enhancement might be attributed to the higher nutrient uptake throughout the crop growth period which in turn increased the plant height, dry matter production and number of tillers $/ \mathrm{m}^{2}$ resulting in higher straw yield (Amin et al., 2008) ${ }^{[3]}$.

\section{Economics}

\section{a. Effect of seed soaking}

Data presented in Table 3 clearly shown that highest total income (₹84755/ha), net realization ( $₹ 67508 / \mathrm{ha}$ ) and BCR (4.91) were obtained with seed soaking with $100 \mathrm{ppm}$ salicylic acid $\left(\mathrm{S}_{2}\right)$, followed by seed soaking with $500 \mathrm{ppm}$ thiourea $\left(\mathrm{S}_{3}\right)$ with total income (₹81690/ha), net realization (₹64429/ha) and BCR (4.73). Further investigation of the data revealed that with the seed soaking with $100 \mathrm{ppm}$ salicylic acid with the additional cost of ₹ $105 /$ ha, there was an increase of ₹18650/ha, which fetched 38.17 per cent higher net realization over control (no seed soaking) and offered 177.62 net incremental cost benefit ratio.

\section{b. Effect of foliar spray}

Data presented in Table clearly shown that highest total income (₹83735/ha), net realization ( $₹ 65977 / \mathrm{ha}$ ) and BCR (4.72) were obtained with seed soaking with $100 \mathrm{ppm}$ salicylic acid $\left(\mathrm{C}_{2}\right)$, followed by seed soaking with $500 \mathrm{ppm}$ thiourea $\left(\mathrm{C}_{3}\right)$ with total income ( $\left.₹ 80845 / \mathrm{ha}\right)$, net realization (62347/ha) and BCR (4.37). Further investigation of the data revealed that with the foliar spray with $100 \mathrm{ppm}$ salicylic acid with the additional cost of ₹ $616 /$ ha, there was an increase of ₹ $115834 /$ ha, which fetched 31.58 per cent higher net realization over control (no seed soaking) and offered 25.70 net incremental cost benefit ratio.

\section{Effect of interaction}

None of the interaction effects between seed soaking and foliar spray of stress mitigating bio-regulators were found significant for all the growth parameters, yield attributes and yield during both the years as well as in pooled analysis.

Table 1: Effect of seed soaking and foliar spray of stress mitigating bio-regulators on periodical plant height and dry matter accumulation of wheat

\begin{tabular}{|c|c|c|c|c|c|c|c|c|}
\hline \multirow{2}{*}{ Treatments } & \multicolumn{4}{|c|}{ Plant height $(\mathrm{cm})$} & \multirow[b]{2}{*}{30 DAS } & \multicolumn{3}{|c|}{ Dry matter accumulation $(\mathrm{g})$} \\
\hline & 30 DAS & 60 DAS & 90 DAS & At harvest & & 60 DAS & 90 DAS & At harvest \\
\hline \multicolumn{9}{|l|}{ Seed soaking } \\
\hline $\mathrm{S}_{0-}$ Control (No seed soaking) & 19.86 & 35.91 & 68.93 & 78.23 & 17.18 & 92.85 & 151.99 & 205.47 \\
\hline $\mathrm{S}_{1-}$ Seed soaking with water & 20.13 & 36.47 & 69.89 & 80.19 & 17.50 & 94.89 & 158.99 & 215.79 \\
\hline $\mathrm{S}_{2-}$ Seed soaking with Salicylic acid (100 ppm) & 21.22 & 40.99 & 76.10 & 87.32 & 18.02 & 111.59 & 195.60 & 268.58 \\
\hline S3- Seed soaking with Thiourea (500ppm) & 21.14 & 40.66 & 74.24 & 86.01 & 17.83 & 109.96 & 190.90 & 261.15 \\
\hline S.Em+ & 0.37 & 0.60 & 1.20 & 1.49 & 0.27 & 1.83 & 2.91 & 3.55 \\
\hline $\mathrm{CD}(\mathrm{P}=0.05)$ & NS & 1.67 & 3.37 & 4.18 & $\mathrm{NS}$ & 5.14 & 8.15 & 9.95 \\
\hline \multicolumn{9}{|c|}{ Foliar spray } \\
\hline $\mathrm{C}_{0}-$ Control (No spray) & 19.89 & 36.18 & 69.10 & 78.75 & 17.22 & 93.19 & 157.54 & 211.22 \\
\hline $\mathrm{C}_{1-}$ Water spray & 20.19 & 36.86 & 70.00 & 80.92 & 17.43 & 95.07 & 161.16 & 219.23 \\
\hline $\mathrm{C}_{2}-$ Salicylic acid spray $(100 \mathrm{ppm})$ & 21.17 & 40.82 & 76.03 & 87.07 & 18.01 & 111.57 & 191.42 & 263.64 \\
\hline $\mathrm{C}_{3}-$ Thiourea spray $(1000 \mathrm{ppm})$ & 21.12 & 40.17 & 74.03 & 85.02 & 17.88 & 109.46 & 187.38 & 256.91 \\
\hline S.Em+ & 0.37 & 0.60 & 1.20 & 1.49 & 0.27 & 1.83 & 2.91 & 3.55 \\
\hline $\mathrm{CD}(\mathrm{P}=0.05)$ & $\mathrm{NS}$ & 1.67 & 3.37 & 4.18 & NS & 5.14 & 8.15 & 9.95 \\
\hline CV (\%) & 10.15 & 8.76 & 9.42 & 10.17 & 8.61 & 10.14 & 9.43 & 8.45 \\
\hline
\end{tabular}

Table 2: Effect of seed soaking and foliar spray of stress mitigating bio-regulators on yield attributes and yield of wheat

\begin{tabular}{|c|c|c|c|c|c|c|c|}
\hline Treatments & $\begin{array}{c}\text { Tiller conversion } \\
\text { index }\end{array}$ & \begin{tabular}{|l|} 
Length of \\
spike $(\mathrm{cm})$
\end{tabular} & $\begin{array}{c}\text { No. of spikelet } \\
\text { / spike }\end{array}$ & \begin{tabular}{|c|}
$\begin{array}{c}\text { No. of Grains/ } \\
\text { spike }\end{array}$ \\
\end{tabular} & \begin{tabular}{|c|} 
Test \\
weight $(\mathrm{g})$
\end{tabular} & \begin{tabular}{|c|}
$\begin{array}{c}\text { Grain yield } \\
(\mathrm{kg} / \mathrm{ha})\end{array}$ \\
\end{tabular} & $\begin{array}{c}\text { Straw yield } \\
(\mathrm{kg} / \mathrm{ha})\end{array}$ \\
\hline \multicolumn{8}{|c|}{ 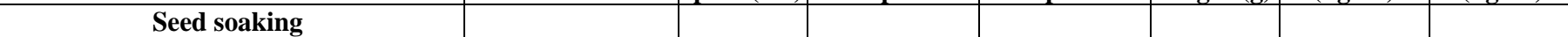 } \\
\hline $\mathrm{S}_{0-}$ Control (No seed soaking) & 72.94 & 8.01 & 14.91 & 53.05 & 54.27 & 1572 & 2196 \\
\hline $\mathrm{S}_{1-}$ Seed soaking with water & 74.32 & 8.17 & 15.34 & 54.54 & 55.79 & 1629 & 2227 \\
\hline 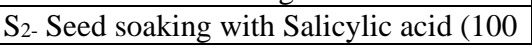 & 81.49 & 10.05 & 19.91 & 58.46 & 58.95 & 2008 & 2895 \\
\hline
\end{tabular}




\begin{tabular}{|c|c|c|c|c|c|c|c|}
\hline ppm) & & & & & & & \\
\hline $\mathrm{S}_{3-}$ Seed soaking with Thiourea $(500 \mathrm{ppm})$ & 81.02 & 9.93 & 19.55 & 58.02 & 58.66 & 1936 & 2786 \\
\hline S.Em+ & 0.95 & 0.15 & 0.28 & 0.97 & 0.76 & 35 & 48 \\
\hline $\mathrm{CD}(\mathrm{P}=0.05)$ & 2.65 & 0.43 & 0.78 & 2.71 & 2.12 & 98 & 135 \\
\hline \multicolumn{8}{|c|}{ Foliar spray } \\
\hline $\mathrm{C}_{0}$-Control (No spray) & 73.08 & 8.10 & 15.12 & 53.19 & 54.64 & 1604 & 2229 \\
\hline $\mathrm{C}_{1}-$ Water spray & 74.61 & 8.26 & 15.65 & 54.24 & 55.51 & 1641 & 2266 \\
\hline $\mathrm{C}_{2}-$ Salicylic acid spray $(100 \mathrm{ppm})$ & 81.51 & 10.05 & 19.78 & 58.54 & 59.03 & 1984 & 2859 \\
\hline $\mathrm{C}_{3}$ - Thiourea spray $(1000 \mathrm{ppm})$ & 80.59 & 9.76 & 19.16 & 58.10 & 58.50 & 1917 & 2750 \\
\hline S.Em+ & 0.95 & 0.15 & 0.28 & 0.97 & 0.76 & 35 & 48 \\
\hline $\mathrm{CD}(\mathrm{P}=0.05)$ & 2.65 & 0.43 & 0.78 & 2.71 & 2.12 & 98 & 135 \\
\hline $\mathrm{CV}(\%)$ & 6.91 & 9.68 & 9.07 & 9.77 & 7.53 & 11.04 & 10.82 \\
\hline
\end{tabular}

Table 3: Economics of durum wheat as influenced by seed soaking and foliar spray of stress mitigating bio-regulators

\begin{tabular}{|c|c|c|c|c|c|c|c|c|c|c|c|c|}
\hline \multirow{3}{*}{ Treatments } & \multirow{3}{*}{$\begin{array}{c}\text { Grain } \\
\text { yield } \\
(\mathrm{kg} / \mathrm{ha})\end{array}$} & \multirow{3}{*}{$\begin{array}{c}\text { Straw } \\
\text { yield } \\
(\mathrm{kg} / \mathrm{ha})\end{array}$} & \multicolumn{3}{|c|}{ Income (₹//ha) } & \multirow{3}{*}{$\begin{array}{c}\text { Total } \\
\text { cost } \\
(₹ / / \mathrm{ha})\end{array}$} & \multirow{3}{*}{$\begin{array}{c}\text { Net } \\
\text { realization } \\
(₹ / h a)\end{array}$} & \multirow{3}{*}{ BCR } & \multirow{2}{*}{\multicolumn{2}{|c|}{\begin{tabular}{|c|}
$\begin{array}{c}\text { Net Increase over } \\
\text { control (₹/ha) }\end{array}$ \\
\end{tabular}}} & \multirow{3}{*}{$\begin{array}{c}\% \text { Increase net } \\
\text { realization } \\
\text { over control }\end{array}$} & \multirow{3}{*}{$\begin{array}{l}\text { Net } \\
\text { ICBR }\end{array}$} \\
\hline & & & \multirow{2}{*}{ Grain } & \multirow{2}{*}{ Straw } & \multirow{2}{*}{ Total } & & & & & & & \\
\hline & & & & & & & & & Cost & Netrealization & & \\
\hline \multicolumn{13}{|l|}{ Seed soaking } \\
\hline So- Control (No seed soaking) & 1572 & 2196 & 55020 & 10980 & 66000 & 17142 & 48858 & 3.85 & - & - & - & - \\
\hline $\mathrm{S}_{1-}$ Seed soaking with water & 1629 & 2227 & 57015 & 11135 & 68150 & 17231 & 50919 & 3.96 & 89 & 2061 & 4.22 & 23.16 \\
\hline $\begin{array}{l}\text { S }_{2-} \text { Seed soaking with Salicylic } \\
\text { acid }(100 \mathrm{ppm})\end{array}$ & 2008 & 2895 & 70280 & 14475 & 84755 & 17247 & 67508 & 4.91 & 105 & 18650 & 38.17 & 177.62 \\
\hline $\begin{array}{l}\text { S }_{3-} \text { Seed soaking with Thiourea } \\
(500 \mathrm{ppm})\end{array}$ & 1936 & 2786 & 67760 & 13930 & 81690 & 17261 & 64429 & 4.73 & 119 & 15571 & 31.86 & 130.8 \\
\hline \multicolumn{13}{|c|}{ Foliar spray } \\
\hline $\mathrm{C}_{0}$-Control (No spray) & 1604 & 2229 & 56140 & 11145 & 67285 & 17142 & 50143 & 3.93 & - & - & - & - \\
\hline $\mathrm{C}_{1}-$ Water spray & 1641 & 2266 & 57435 & 11330 & 68765 & 17498 & 51267 & 3.93 & 356 & 1124 & 2.24 & 3.15 \\
\hline $\mathrm{C}_{2}-$ Salicylic acid spray $(100 \mathrm{ppm})$ & 1984 & 2859 & 69440 & 14295 & 83735 & 17758 & 65977 & 4.72 & 616 & 15834 & 31.58 & 25.70 \\
\hline $\mathrm{C}_{3}$ - Thiourea spray $(1000 \mathrm{ppm})$ & 1917 & 2750 & 67095 & 13750 & 80845 & 18498 & 62347 & 4.37 & 1356 & 12204 & 24.33 & 9.00 \\
\hline
\end{tabular}

Selling price: Grain: ₹ $35 / \mathrm{kg}$, Straw: ₹ $5 / \mathrm{kg}$

\section{Conclusion}

In light of the above results and discussion it could be concluded that durum wheat should be seed soaked with 100 ppm salicylic acid $(0.1 \mathrm{ml} / 1$ lit. water for $\mathrm{kg}$ of seed) or with $500 \mathrm{ppm}$ thiourea $(0.5 \mathrm{~g} / \mathrm{lit}$ of water per $\mathrm{kg}$ seed $)$ for obtaining higher growth and yield attributes as well as grain and straw yield. The highest net realization, BCR and net ICBR could be fetched for the same treatments.

\section{Reference}

1. Abreu ME, Bosch SM. Salicylic acid deficiency in NahG transgenic lines and sid 2 mutants increases seed yield in the annual plant Arabidopsis thaliana. J Exp. Bot. 2009; 60:1261-1271.

2. Ahmad H, Khan I, Liaqat W, Jan MF, Dawood MA. Effect of Salicylic Acid on Yield and Yield Components of Maize under Reduced Irrigation. International Journal of Environmental Sciences \& Natural Resources, 2018, 9(2).

3. Amin AA, Rashad F, Gharib AE. Change in morphological physiological and reproductive characters of wheat plants as affected by foliar application with salicylic acid and ascorbic acid. Australian Journal of Basic and Applied Sciences. 2008; 2(2):252-261.

4. Anonymous. https://en.wikipedia.org/wiki/Bhalia_Wheat.

5. Anonymous. State Agriculture Plan \& State Infrastructure Development Plan (SAP \& SIDP) (201718 to 2019-20) Gujarat, 2018.

6. Arfan M, Athar HR, Ashraf M. Does exogenous application of salicylic acid through the rooting medium modulate growth and photosynthetic capacity in two differently adapted spring wheat cultivars under salt stress. J Plant Physiol. 2007; 164(6):685-694.
7. Ashraf MA, Iqbal M, Rasheed R, Hussain I, Riaz M, Arif MS. Environmental stress and secondary metabolites in plants: an overview. Plant Metabol. \& Regul. Under Environ. Stress. Elsevier, 2018, 153-167.

8. Ashraf MN, Akram A, Arteca RN, Foolad MR. The physiological, biochemical and molecular roles of brassinosteroids and salicylic acid in plant processes and salt tolerance. Crit. Rev. Plant Sci. 2010; 29:162-190.

9. Chouhan KS, Kakralya BL, Bajya M, Sodani R. Salicylic acids mitigate the adverse effect of high temperature stress on yield and yield determining parameters of wheat (Triticum aestivum L.) Journal of Pharmacognosy and Phytochemistry. 2017; 6(4):1052-1055.

10. Dadhich RK, Meena RS. Performance of Indian mustard (Brassica juncea L.) in response to foliar spray of thiourea and thioglycollic acid under different irrigation levels. Indian Journal of Ecology. 2014; 41(2):376 - 378.

11. Dadhich RK, Meena RS, Reager ML, Kansotia BC. Response of bio-regulators to yield and quality of Indian mustard (Brassica juncea L. Czernj. and Cosson) under different irrigation environments. Journal of Applied and Natural Science. 2015; 7(1):52-57.

12. Giaquinta RT. Evidence of phloem loading from apoplast: chemical modification of membrane sulphydryl group. Plant Physiology. 1976; 58(5):872-875.

13. Hall AE. Crop Response to Environmental Stress. CRC Press LLC, Boca Ramon, Florida, 2011.

14. Hayat QS, Hayat Irfan M, Ahmad A. Effect of exogenous salicylic acid under changing environment: A review. Environ. Exp. Bot. 2010; 68:14-25.

15. Janda T, Gondor OK, Yordanova R, Szalai G, Pal M. Salicylic acid and photosynthesis: signalling and effects. Acta Physiol. Plant. 2014; 36(10):2537-2546.

16. Jatana BS, Ram H, Gupta N. Application of seed and foliar priming strategies to improve the growth and 
productivity of late sown wheat (Triticum aestivum L.). Cereals research communication. 2020; 48:383-390.

17. Karim FM, Mohammed Q, Khursheed S. Effect of foliar application of salicylic acid on growth, yield components and chemical constituents of wheat. Biology Dept., Education College- Scientific Department, University of Salahaddin- Erbil, Kurdistan region, 2011.

18. Khan SU, Bano A, Gurmani AR. Abscisic acid and salicylic acid seed treatment as potent inducer of drought tolerance in wheat (Triticum aestivum L.). Pak. J Bot. 2012; 44:43-49.

19. Knorzer OC, Lederer B, Durner J, Boger P. Antioxidative defense activation in soybean cells. Physiol. Plant. 1999; 107:294-302.

20. Kumar K, Singh SN, Singh RK, Singh OP. Effect of several doses of boron and thiourea on morphophysiological characters and harvest index of wheat varieties in different sowing conditions. International Journal of Chemical Studies. 2018; 6(2):3690-3696.

21. Li T, Hu Y, Du X, Tang H, Shen C, Wu J. Salicylic acid alleviates the adverse effects of salt stress in Torreya grandis cv. Merrillii seedlings by activating photosynthesis and enhancing antioxidant systems. PLoS One. 2014; 9(10):109-112.

22. Mandava N.B. Plant growth-promoting brassinosteroids. Annu. Rev. Plant Physiol. Plant Molec. Biol. 1988; 39:23-52.

23. Meena VK, Kaushik MK, Meena RS, Meena VS, Meena BP. Effect of Growth Regulators on Clusterbean [Cyamopsis Tetragonoloba (L.)] Growth Under Aravali Hills Environment In Rajasthan. The Bioscan. 2014; 9(2):547-550.

24. Miura K, Tada Y. Regulation of water, salinity, and cold stress responses by salicylic acid. Front. Plant Sci. 2014, 5.

25. Nazar R, Iqbal N, Syeed S, Khan NA. Salicylic acid alleviates decreases in photosynthesis under salt stress by enhancing nitrogen and sulfur assimilation and antioxidant metabolism differentially in two mungbean cultivars. J Plant Physiol. 2011; 168(8):807-815.

26. Nisar Ahmed, Amanullah, Tahir Jamal. Effect of seed soaking in nitrogen, phosphorus and herbicides solution on yield and other characteristics of wheat. Sarhad J. Agric. 2007; 23:1.

27. Sahu MP, Solanki NS, Dashora NL. Effect of thiourea, thiamine and ascorbic acid on growth and yield of maize (Zea mays L.). Journal of Agronomy and Crop Science. 1993; 171:65-69. 